\title{
Marshall, Schumpeter and the Shifting Boundaries of Economics and Sociology
}

\author{
Geoffrey M. Hodgson
}

Draft of 31 January 2007

\begin{abstract}
The Business School, University of Hertfordshire, De Havilland Campus, Hatfield, Hertfordshire AL10 9AB, UK www.geoffrey-hodgson.info

g.m.hodgson@herts.ac.uk
\end{abstract}

\begin{abstract}
Both Alfred Marshall and Joseph Schumpeter pronounced on the scope and boundaries of economic theory. For Marshall, economics was a broad subject, concerned primarily with business and pecuniary matters. Marshall also aligned himself with the methodological ideas of Gustav Schmoller, even after the outbreak of the Methodenstreit in 1883. Schumpeter reacted differently to the Methodenstreit by arguing that much of the work of Schmoller and others in the German historical school was 'economic history' or 'economic sociology' rather than 'economic analysis'. Also Schumpeter's close contact with Talcott Parsons and Paul Samuelson at Harvard University from 1927 was probably significant in their redrawing the boundaries of both economics and sociology, although they did not strictly follow Schumpeter's criteria. Following Lionel Robbins, economics was redefined more narrowly as the 'science of choice'. Sociology was concerned with the explanation of values and ends. However, by the 1990s these disciplinary definitions were breaking down, and a major reexamination of their scope and boundaries is required.
\end{abstract}




\title{
Marshall, Schumpeter and the Shifting Boundaries of Economics and Sociology
}

\author{
Geoffrey M. Hodgson
}

Alfred Marshall and Joseph Schumpeter rank as two of the most important and enduringly influential economists of all time. ${ }^{1}$ They both had a major impact on the development of economics in the twentieth century. Their writings have several common characteristics, including minimal explicit reliance on mathematics, a rich grounding knowledge of the social and behavioural sciences, a methodological and philosophical awareness, fluently engaging styles of writing, and a primary concern to explain the world rather than to exhibit knowledge or technique for their own sake.

Although Marshall was not the originator of the key idea of marginal utility, in the 1880s he played a crucial role by synthesizing the paradigm that Thorstein Veblen (1900, p. 261) was later to describe as 'neoclassical' (Ekelund and Hébert, 2002). Marshall was the main systematizer of the partial equilibrium variant of neoclassical theory, which held sway in Britain, the United States and elsewhere until it began to be displaced by the Walrasian general equilibrium approach at around the time of the Second World War. Nevertheless, Marshall remained hugely influential throughout the twentieth century.

Both Schumpeter and John Maynard Keynes were born in 1883. Marshall died in 1924, leaving his former pupil and the Austrian economist to tackle the catastrophic global events of the Great Depression in the 1930s. Schumpeter and Keynes took very different views on this issue. Schumpeter (1931) initially proposed that the downturn was the unfortunate but unavoidable outcome of the coincidence of the three troughs of the fifty-year Kondratieff cycle, with the shorter Juglar and Kitchin cycles. By contrast Keynes (1936) saw the fall in 'effective demand' as the key explanatory factor, and promoted government expenditure to increase aggregate demand for goods and services. Keynes's analysis and policy proposals proved more influential at the time.

In the 1930s and 1940s Schumpeter $(1934,1942)$ offered other major insights, including analyses of the relationship between technological development, political institutions and economic activity. Despite these major contributions, overall Keynes was more influential than Schumpeter, at least from the 1940s to the 1970s.

However, since the 1980s Schumpeter's overall contribution has enjoyed a justified renaissance, with an explosion of secondary literature devoted to his life and work. Nevertheless, some important and related aspects of his thought are less widely discussed. They concern his views on the boundaries of economics as a science and his related appraisal of the contribution of the German historical school. Here in several respects there are contrasts with the ideas of Marshall. Indeed, the most important argument in this essay is that Schumpeter played a role alongside others in redefining the boundaries and scope of both

\footnotetext{
1 This article makes use of some material from Hodgson (2001). I am extremely grateful to Markus Becker., Mark Blaug and Thorbjørn Knudsen for extensive critical comments on a previous draft, including the correction of several significant errors. Others including Yanis Varoufalis are also thanked for their helpful suggestions.
} 
economics and sociology. A narrower definition of economics emerged in the Anglophone world in the 1930s and it eventually displaced the previous and wider definition of the subject held by both Marshall and the German historical school.

The conclusion of this essay assesses this legacy and points out that the boundaries are now being transgressed from both sides. This means that a reassessment of the boundaries and relations between economics and sociology is in order.

\section{Marshall and the German Historical School}

The historical school prospered in the German-speaking world from the 1840s to the 1930s and went through several phases of development (Hodgson, 2001). Throughout its existence its members argued that national economic systems differed substantially in time and place and emphasized the importance of historically sensitive theory. However, in its early years this school was marked by a naïve empiricism, involving a faith in the explanatory role of facts alone. In the opening salvo of the so-called Methodenstreit, Carl Menger (1883) developed a powerful methodological attack on these empiricist views. Menger brought the thinking and acting individual to the centre of the methodological discussion. He argued that some a priori theoretical principles were essential in order to understand economic phenomena.

Furthermore, Menger ([1883] 1985, p. 49) identified 'that error which confuses theoretical economics with the history of economy' and tried instead to establish a central place in economics for deductive and abstract theory. Menger ([1883] 1985, p. 87) argued that economics should be concerned with the aspect of human life concerned with economising action, that is 'the manifestations of human self-interest in the efforts of economic humans aimed at the provision of their human needs'. Accordingly, the Methodenstreit was not simply about methodology, it was also about the legitimate boundaries of economics as a discipline.

While members of historical school generally retained a broad view of the subject, the Methodenstreit caused several of their leaders to refine their methodological views and abandon any exclusive reliance on empirical evidence alone. Schmoller (1900, p. 109) proposed a combination of inductive evidence with deductive theory as a means of revealing and understanding causal relations. His pupil Werner Sombart became the de facto leader of the historical school after his teacher's death in 1917. Notably, Sombart (1929, p. 1) criticized 'the mistaken idea that history can be approached without theory' and attempts 'to banish all theory from the investigation of historical reality.' For Sombart (1929, p. 3): 'Theory is the pre-requisite to any scientific writing of history.' The Austria and later historical schools differed not in terms of being one against and the other for theory, but on the type of theory they proposed.

Although Marshall was educated largely in England and Schumpeter in Austria and Germany, they both were highly influenced by the German historical school. ${ }^{2}$ Marshall was fluent in German. Like many aspiring young economists in the nineteenth century, he went to Germany to study under the tutelage of members of the historical school. Contrary to some accounts, he was not an opponent of this school of thought (Hodgson, 2001, 2005).

\footnotetext{
2 The influence of the German historical school on Schumpeter has been more widely discussed. See Machlup (1951), Swedberg (1989), Streissler (1994), Chaloupek (1995), Shionoya (1997), Ebner (2000) and Hodgson (2000).
} 
Marshall's longstanding opposition to the views of William Cunningham in Cambridge focused largely on Cunningham's (1892) claim that valid general theoretical principles were unobtainable and consequently that economics had to be largely descriptive and taxonomic. Marshall's stance did not signal any opposition to the historical school as a whole. Instead, Cunningham represented the more naïve empiricist views of some German economists in the years before the Methodenstreit. Significantly, even in his critiques of Cunningham, and repeatedly elsewhere, Marshall $(1895,1890,1892,1897)$ endorsed key historical school arguments (Hodgson, 2001).

Some commentators take a different view. Robert Skidelsky (1983, p. 43) for example stated that Marshall 'rejected the main contentions of the German historical school'. There is no evidence for this. On the contrary, in his works, Marshall heaped praised on Schmoller and other German writers, including in the later editions of his Principles. For Marshall, Schmoller was a foremost methodological inspiration. In the opening pages of his definitive text, Marshall (1920, p. 29) quoted and endorsed Schmoller's methodological statement that: 'Induction and deduction are both needed for scientific thought as the left foot and the right foot are both needed for walking.' In his letters, Marshall repeated this endorsement of Schmoller's attempt to steer a midway course between empiricism and deductivism. Marshall wrote on 30 January 1897: 'Most of the suggestions which I made on the proofs of [John Neville] Keynes's Scope and Method were aimed at bringing it more into harmony with the views of Schmoller' (Whitaker, 1996, vol. 2, p. 179). Ten years later, at his address at a dinner of the Royal Economic Society, Marshall (1907, p. 7) optimistically declared:

Disputes as to method have nearly ceased; Schmoller's dictum that analysis and the search for facts are, like the right and left foot in walking, each nearly useless alone, but that the two are strong in combination, is accepted on all sides.

Contrary to a modern myth that Marshall was an opponent of the German historical school, Marshall (1920, p. 768) retained a highly laudatory view of their work, seeing it as 'one of the great achievements of our age'

Accordingly, Gerard Shove (1942, p. 309) later remarked: 'If any school of thought outside the Ricardian tradition set its mark on the Principles it was the Historical School, rather than the marginal utility school, that did so.' Similarly, Terence Hutchison (1988, p. 529) wrote: 'Alfred Marshall, under German influence, made a strenuous attempt to re-graft a historicalinstitutional approach on to the neo-classical abstraction.'

Overall, rather than taking sides with Menger in the Methodenstreit, Marshall proposed that historically grounded insights should enrich and to some extent qualify the apparatus of neoclassical theory. His partial equilibrium approach provided scope for data reflecting historical, institutional and cultural contexts, within which partial adjustments of price or quantity variables may be considered.

\section{Marshall's Definition of Economics}

There is not the space here to review earlier conceptions of the scope and boundaries or economics. Marshall's view on this point was broadly consistent with many economists before him. William Stanley Jevons (1888, p. vi), for instance, saw economics as the 'science of the development of economic forms and relations'. Similarly, Marshall's definition of economics was sufficiently broad to accommodate historical and other insights within the discipline. For Marshall (1920, p. 1): 
Political Economy or Economics is the study of mankind in the ordinary business of life; it examines that part of individual and social action which is most closely connected with the attainment and with the use of the material requisites of wellbeing. Thus it is on the one side a study of wealth; and on the other, and more important side, a part of the study of man.

Although Marshall preferred the term 'economics' to the earlier one of 'political economy', this choice did not for him signal a narrowing of the legitimate subject matter of the discipline. On the contrary, Marshall (1920, p. 43) saw political economy as the narrower term' because it often referred merely to discourses on politically desirable economic policies, rather than the analysis of 'the best methods' of reaching proposed ends. However, in adopting a broad definition of the subject, Marshall implicitly leaves space for other social sciences, as the scope of economics was not universal. For Marshall (1920, p. 22) economics had a core preoccupation:

'money' or 'general purchasing power' or 'command over material wealth,' is the centre around which economic science clusters; this is so, not because money or material wealth is regarded as the main aim of human effort, nor even as affording the main subjectmatter for the study of the economist, but because in this world or ours it is the one convenient means of measuring human motives on a large scale.

Hence for Marshall, economics is not exclusively concerned with pecuniary values but they are the most convenient data available to examine human motives and behaviour 'in the ordinary business of life'. Within his broad and inclusive conception of the subject, prices and other monetary values play central roles. This conceded potential territory to other social sciences such as anthropology and sociology, but left the boundaries rather vague.

He focused on individual motives but did not always take them as given, or entirely selfregarding. For Marshall (1920, p. 89) tastes were malleable, as 'the development of new activities giving rise to new wants.' Furthermore, for him, the incorporation of changing wants or preferences was entirely within the scope of economic theory. As noted below, this inclusive view was later to be overturned by mainstream economists.

Notably, Marshall did not react to the Methodenstreit by drawing from Menger a narrower conception of economics, based on the universal logic of choice based on individual selfinterest. While Marshall defended the role of core theoretical principles, his definition of economics remained broad and inclusive. Marshall wrote to Francis Edgeworth on 28 August 1902: "In my view "Theory" is essential. ... But I conceive no more calamitous notion than that abstract, or general, or 'theoretical' economics was economics "proper." (Whitaker, 1996, vol. 2, p. 393)

Marshall's definition of economics in terms of 'the study of mankind in the ordinary business of life' did not define the discipline in terms of assumptions or methods, but in terms of a real object of zone or analysis. However, this zone was not itself sharply defined. Economics was instead a locus of concern within the broader social sciences as a whole. This picture was consistent with the then influential conception of Auguste Comte who, in defining and coining the term 'sociology', saw it broadly as the study of society, with economics as a specialist and subordinate discipline within.

Marshall's wide interpretation of the boundaries of economics endured for several decades. This was true in both Britain and the United States at least until the 1940s. This inclusive spirit sustained not only capacious disciplinary boundaries but also the tolerance of different theoretical approaches and schools of thought. This pluralistic spirit was evident when 
Edgeworth (1891, p. 1), a leading neoclassical economist and first editor of the Economic Journal, opened the first volume: 'The Economic Journal ... will be open to writers of different schools. The most opposite doctrines may meet here as on a fair field. ... Nor will it be attempted to prescribe the method, any more than the result, of scientific investigation.'

Notably the American institutionalists, who were dominant in the United States in the interwar period, inherited a broad conception of the discipline from both Marshall and the historical school. Wesley Mitchell was the most eminent and influential institutional economist after the death of Veblen in 1929. Mitchell (1916, p. 157) was echoing Marshall when he wrote: 'Money may not be the root of all evil, but it is the root of economic science.' Like many other institutionalists, Mitchell incorporated key elements of Marshallian theory within his work, regarding the two as generally compatible. Veblen is often depicted as taking a contrasting, more iconoclastic and anti-neoclassical position. However, in lectures delivered in 1926-27, Mitchell (1969, vol. 2, p. 685) pointed out that 'Veblen himself at times makes casual, implicit use of orthodox economic theory' and gave some evidence in support of this contention.

In sum, Marshall followed the German historical school and others in adopting a relatively broad conception of the scope of economics as a discipline. Concerned with 'the study of mankind in the ordinary business of life' it would focus especially on potentially malleable human motives and individual incentives, as particularly expressed in decisions with pecuniary outcomes. Consequently from Adam Smith to Marshall, a broad and inclusive definition of economics prevailed, in both Germany and the Anglophone world. Economics was widely conceived as the study of economic, precuniary or business phenomena. However, within a few years of Marshall's death, this situation was to change radically.

\section{Schumpeter's Reaction to the Methodenstreit and His Definitions of Economic Analysis}

Schumpeter (1941, p. 239) long admired the general equilibrium approach of Léon Walras, regarding him as 'the greatest of all theorists' while rejecting Marshall's .vision of the economic process, his methods, his results'. One of Schumpeter's enduring but unfulfilled ambitions was to dynamize the Walrasian theoretical system.

Influenced by both the Austrian and German historical schools in the Methodenstreit, Schumpeter (1908, pp. 6-7) came to the conclusion that 'both sides are mostly right ... their sole difference lies in their interests in different problems.' He further argued that their differences were largely due to different disciplinary preoccupations: compared with Menger and his followers, the historical school were less concerned with 'pure theory' or 'pure economics'. Schumpeter (1908) upheld the value of contributions on both sides, and maintained himself a strong interest in economic development, but he regarded the latter as outside the strict realm of 'pure economics', which was essentially static in nature (Shionoya, 1997, pp. 126-9).

In a work where there is much discussion of the boundaries of economics and its subdivisions, Schumpeter upheld in some passages that 'economic analysis' or 'pure economics' started from the assumption of universal regularities in human behaviour such as an inverse relation between price and quantity consumed. For example, Schumpeter (1908, p. 
64) wrote: 'The fact we see is only that the individual offers a decreasing price. Why he does so is not interesting from the standpoint of economics. ${ }^{3}$

On this passage Shionoya (1997, p. 116) comments: 'It is clear that when Schumpeter said this he had Menger in mind.' But Schumpeter went further than Menger, to declare that the causes of wants and how they are satisfied were outside the realm of economic theory. Psychology as a whole was seen as separate from economics. This exclusion of psychological insights from economics was too radical even for some Austrians, and it drew criticism from Schumpeter's teacher Friedrich von Wieser (Shionoya, 1997, pp. 117-18). Instead Schumpeter focused foundationally on presumed regularities of exchange behaviour. Although Schumpeter did not use these terms, this idea was consistent with the views of Menger and others who upheld that in economics wants or preference function are taken as given. ${ }^{4}$ Like many other economists that take such a basic view, Schumpeter accepted that wants may change, but saw the investigations of these causes as outside economic analysis.

Similarly, Schumpeter (1909, p. 216) wrote in an article published in English in the following year: 'For theory it is irrelevant why people demand certain goods: the only important point is that all things are demanded, produced, and paid for because individuals want them.' For him, the task of theory was to consider the outcomes of individual decisions, individual interactions and their consequences, but not on the causes of their wants or preferences. ${ }^{5}$

Schumpeter (1908) defined the overall subject matter of 'economics' in terms of the formal analysis of 'exchange relations' or catallactics. Influenced in this respect by Walras, Schumpeter saw the basic unit of analysis as the reciprocal transfer of goods. Also like Walras, Schumpeter retained the concepts of utility and utility maximization. As Shionoya (1997, p. 134) puts it, 'the quantity of goods and utility functions were assumed as given, but this assumption was made to treat the phenomenon of exchange as the first step in the analysis.'

Schumpeter (1908) went further than Walras, however, in regarding 'exchange' as a highly general concept, occurring in production and consumption as well as trade. Schumpeter's aim was to demarcate and develop an ahistorical and highly abstract system of 'pure economics', applicable to all past and possible forms of human activity. Any study of historical specific institutions was thus outside 'pure economics' thus conceived.

Adopting the ideals of this abstract and general project, he maintained a view that other approaches were not economic theory proper. Schumpeter (1928, p. 363) wrote in the Economic Journal: "within serious economic theory there are no such things as "schools" or

${ }^{3}$ See Schumpeter (1908, pp. 64-8, 77-9, 85-91, 154-5, 261, 541-7).

${ }^{4}$ As Shionoya (1997) explains, Schumpeter was strongly influenced by Ernst Mach's positivism and its stress on observable behaviour. Hence in his 1908 book Schumpeter focuses on the behavioural regularities rather than explicit assumptions about wants or preferences. However, in its demarcating effects, his 1908 position is identical to the idea of taking wants as given, or assuming given preferences, as a basis for the definition of the boundaries of economic theory.

5 Schumpeter (1909, p. 216) also admits the study of 'social wants' as within economic theory, but only on condition that they can be accounted for by 'individuals acting as a community consciously and jointly'. Again, for him, the appropriate focus for theory is on explanations in terms of individuals, but not on explanations of the origins of individual wants themselves. 
differences of principles, and the only fundamental cleavage in modern economics is between good work and bad.' However, in a Japanese journal in 1931 Schumpeter later modified this view to the empirical claim that there are "no differences as to fundamental standpoints among serious economists' but he was unclear as to whether institutionalists or members of the historical school were included in this 'serious' group (quoted in Shionoya, 1997, p. 63). Overall, Schumpeter allowed only no more than a highly limited plurality of approaches within the core of theoretical economics.

After 1908 Schumpeter rarely revisited his definition of economics in terms of the formal analysis of 'exchange relations' or catallactics. While he gave more and more attention to dynamic analysis and economic development, some but not all later statements suggest the retention of a narrow definition of 'economic analysis'. In some passages he broke the strict stipulations of the boundaries of economics in his 1908 book; in other mature statements he reaffirmed them. ${ }^{6}$

For example, in a posthumously published book, Schumpeter (1954, p. 21) wrote: "economic analysis deals with the questions how people behave at any time and what the economic effects are they produce by so behaving; economic sociology deals with the question how they came to behave as they do.' Although Schumpeter had made other statements with different connotations, this statement by him is consistent with the postwar consensus established by Lionel Robbins, Paul Samuelson and Talcott Parsons. Note that 'economic' in this passage is the adjective rather than the noun in both 'economic sociology' and 'economic history'. Schumpeter promoted neither 'sociological economics' nor 'historical economics' as descriptive terms. This logically would suggest that economic sociology is a branch of sociology and economic history is a branch of history, neither being in economics proper.

However, Schumpeter did not consistently pursue this line of argument in his work as a whole, and after 1908 he is generally vague about the boundaries of 'economics' as such, apart from occasional and important statements concerning the inclusion of 'history' and 'statistics' within economics. For example, in another passage in this last book, Schumpeter (1954, p. 12) elliptically and briefly put 'history' as part of 'economic analysis'.

Nevertheless, in yet another passage from this book, Schumpeter $(1954$, p. 819) suggested that the study of institutions, including 'economic institutions', was the subject matter of 'economic sociology' rather than economics. One awkward logical consequence is that if markets are institutions, as several economists and sociologists uphold (Fligstein, 2001; Hodgson, 1988; Lie, 1997; Solow, 1990), then the study of markets is not the subject of economic analysis. Another awkward corollary is that the work of 'new institutional economists' - including Oliver Williamson and Nobel Laureates in economics such Ronald Coase and Douglass North - do not qualify as economic theory or analysis by Schumpeter's (1954, p. 819) suggestion. However, as noted below, Schumpeter somewhat qualified his position elsewhere, by recoiling from such restrictions. He did not follow the logic of this remark to its conclusion and more generally his statements on these issues are patchy, incomplete and partially inconsistent.

\footnotetext{
6 Schumpeter later expressed some dissatisfaction with his 1908 position. Ludwig Lachmann recollected that in in London 1936 Robbins asked Schumpeter why Das Wesen had not been published into English. Schumpeter replied: 'Because I don't like it ... There are things in it I no longer believe' (Mittermaier, 1992, p. 11).
} 
Ironically, much of Schumpeter's work, largely upon which his currently high reputation is built, was in the sphere of 'economic sociology' by some of his definitions. This is true of especially influential works such as his Capitalism, Socialism and Democracy (1942). Schumpeter frequently narrowed the definition of 'economic analysis' but always he saw it as extremely important to broaden the mind by travel across its boundaries. He also argued that the social science disciplines should learn from one another.

As Shionoya $(1990,1997)$ highlights, a key piece of evidence here is the seventh chapter in the Theory of Economic Development, omitted from the second German edition and from the English translation (Schumpeter, 1912, 2002). Here Schumpeter (2002, p. 94) argues that after the study of the 'static system ... economic development poses the second most important problem faced by economists'. This chapter has a particularly interesting passage, suggesting some equivocation. Schumpeter (2002, p. 97) writes:

Pure economic laws are similar to the laws of mechanics which tell us how bodies with mass behave under the influence of any external 'forces', but which do not describe the nature of those 'forces'. ... In the same way pure economics provides us with formal laws as to how the economy is shaped under the influence of conditions coming from the outside. ... Therefore, in such a conception, pure economics almost by definition excludes the phenomenon of a 'development of the economy from within'.

Yet in the next paragraph Schumpeter (ibid.) immediately qualifies the above statement:

Only rarely will such a conception be formulated explicitly. Frequently, it is the very reason for the silence of the theoreticians on the phenomenon of development itself; this corresponds to the standpoint of many of the best theorists. We do not completely deny that such a conception might be justified. It is true that this way of thinking corresponds to the fundamental principles of static economics. ... Those static laws are the basis of a scientific understanding of the economy. And to explain those effects is an important task of theoretical economics. As an abstraction, this conception is justified, even indispensable.

Observe the equivocation here. After noting with regret that traditional 'pure economics almost by definition' excludes the critical phenomenon of economic development, Schumpeter cannot quite bring himself to overturn this definition. Hence the equivocal phraseology when he does 'not completely deny that such a conception might be justified'. But he does not partially deny it either.

Nevertheless, this seventh chapter is an important piece of evidence that Schumpeter wished to establish a broader conception of economics in which economic development and dynamics were major themes. Shionoya $(1990,1997)$ suggests on the basis of this chapter that Schumpeter was moving towards the idea of a unified social science. Perhaps so, but the next section shows that Schumpeter remained equivocal on the important matter of the boundaries between the social sciences.

\section{Schumpeter's Journey to Harvard}

Schumpeter's explicit attitude to the German historical school shifted remarkably in a short period of time. This period coincides with the shift of Schumpeter's interests and employment from the University of Bonn in Germany to Harvard University in the United States. As a result of this move, Schumpeter was involved with authors who played a major part in the redrawing the boundary between economics and sociology, and who helped to establish the consensus on these disciplinary boundaries after the Second World War. 
We address these developments chronologically. As late as 1926 Schumpeter published a sympathetic account of the work of Schmoller and other historical school theorists. In this article Schumpeter (1926a, pp. 3, 18, 22, 24 n., 46) wrote of Schmoller's 'great achievements', of his 'greatness', of his work being 'the programme for the future', of 'his overall achievements' and of his 'success'. In the same article, Schumpeter saw much merit in the work of the leading American institutionalist Wesley Mitchell. Although he also raised thoughtful criticisms, the disposition was largely positive. Within four years, however, Schumpeter was to shift the balance of his assessment of historicism and institutionalism, towards criticism alone.

Schumpeter made another significant decision at this time. In producing the second (1926) German edition of his Theory of Economic Development, Schumpeter decided to drop its rich and important seventh chapter, discussed above. This chapter was also omitted from the later English edition (Schumpeter, 1912, 1926b, 1934). On this issue, John Mathews (2002, p. 2) asks:

Why then, did Schumpeter drop this innovative chapter from the second edition, and never refer to it again in his own published work? There is no clear or easy answer to this question. Perhaps he saw it as too precocious, too bold, and not appropriate for a mature man who by now aspired to a professorship at Harvard ...

There is no evidence that Schumpeter wanted a job at Harvard as early as 1926, and he certainly continued for a while to retain professional aspirations in Germany. However, Harvard was definitely in his sights, as he was a visiting professor at that university in 192728. At a time when many leading US departments of economics were dominated by institutionalists, Harvard inclined more to neoclassical ideas. An obvious explanatory hypothesis is that the broader conception of economics suggested in this chapter of the 1912 work was seen as too inclusive for the sensibilities of Harvard economists. His 1926 book was of course published in German, but at that time the majority of US economists could read that language, given the relative global importance of the German literature in economics. Also after 1926, Schumpeter became more openly critical of the historical school and highly dismissive of the institutionalist tradition. ${ }^{7}$

In the Harvard-based Quarterly Journal of Economics Schumpeter (1930, p. 158) referred scathingly to the intellectual capacities of both Schmoller and Veblen, and to 'the serious and even glaring defects in their equipment, both natural and acquired.' Schumpeter (1930, p. 159) also pronounced on the 'unsatisfactory state of economic science in Germany' and dismissed Veblen's work without adequately detailed criticism. In a talk in Japan in 1931, Schumpeter (1991, p. 292) referred to the 'methodological errors of German historians'. He also described institutionalism as 'the one dark spot in the American atmosphere'. Overall, there was a remarkable transformation from Schumpeter's sympathetic 1926 article on Schmoller, to the largely hostile statements of 1930-31, in which Schumpeter was keen to dismiss, and to detach himself from, the entire German historical school and American institutionalism. These negative statements may have aided his application for a permanent post in Harvard.

\footnotetext{
7 Strikingly, some of the positive appraisals of German historicists in Schumpeter (1926b) were removed from the first English edition of that work. Compare, for instance, the positive footnote on Sombart in Schumpeter (1926b, p. 90 n.) with Schumpeter (1934, p. 61).
} 
Schumpeter attained a permanent post in Harvard in 1932. He had really wanted to get Sombart's former chair in Berlin when it became vacant in 1931 but he was unsuccessful. Schumpeter's move to Harvard coincided with an increasing criticism of both the institutionalist and historical school traditions. ${ }^{8}$ Yet the irony is that Schumpeter continued throughout his life to draw on the work of the German historical school and many of Schumpeter's ideas are traceable to their leading scholars. ${ }^{9}$

At the same, Schumpeter's residence in Harvard provided him with the opportunity to participate in discussions concerning the redrawing of the boundaries of economics itself, and particularly between economics and sociology. In this and other respects, his personal contacts with both Parsons and Samuelson in Harvard were important.

\section{The Recasting of Economics and Sociology}

Previously educated in the American institutionalist tradition, 1927 Parsons was appointed an instructor in economics at Harvard University. He took Schumpeter's economics classes and discussed a number of issues with him (Brick, 1993). At this time, Parsons was shifting away from institutionalism and was becoming more sympathetic to the mainstream economists at Harvard (Camic, 1992). Schumpeter encouraged Parsons to study the work of Vilfredo Pareto, which had attracted the interest of a number of Harvard economists. Importantly for Parsons's line of research, Pareto had attempted a general theory in both economics and sociology, and tried to establish a boundary between the two disciplines.

Parsons had previously studied in Germany and was a translator of some of Max Weber's works into English. As David Zaret (1980, p. 1193) has argued, 'Parsons saw in Weber's writings a non-Marxian foundation for general theory.' The general theory for which Parsons aspired was to be even more general than the Paretian and Walrasian approaches admired by Schumpeter. As Hans Joas (1995, p. 275) pointed out: 'by dint of the approach he was taking, Parsons realized that he was being forced out of the prestigious discipline he had started his career in.' In 1931 Parsons transferred to a newly founded department at Harvard, which was eventually named the department of sociology. 'Sociology offered Parsons a way out of this personal and theoretical crisis as well as a solution to the problem of the definition of the proper field of economics' (ibid.).

Parsons became deeply engaged with the problem of demarcation between economics and sociology. To accommodate culture and institutions while rejecting the role of biology or instinct, sociology itself had to be transformed. Furthermore, it had to reach a new modus vivendi with the rising new wave of neoclassical economics and preserve its own intellectual territory. As Parsons (1970, p. 827) himself remarked: 'It gradually became clear to me that economic theory should be conceived as standing within some sort of theoretical matrix in which sociological theory also was included.'

Parsons and Schumpeter were both strongly influenced by Pareto and his distinction between 'logical' and 'non-logical' actions. Pareto saw 'logical' actions as being those where means were consistent with, and appropriate for, the given ends. For Pareto (1971), the study

\footnotetext{
${ }^{8}$ A possible but unproven motive for this shift is discussed in Hodgson (2001, pp. 189-90).

9 For example, Schumpeter's famous phrase ‘creative destruction' has a precedent in a work by Sombart (1913, p. 207). See also Appel (1992, pp. 260-2).
} 
of such 'logical' actions was the domain of economics. On the other hand, like Weber, Pareto (1935) upheld that the residual class of 'non-logical' actions governed much of human behaviour. Such actions were seen as the subject matter of sociology. Accordingly, economics was a limiting case of the broader theory of social action that it was the task of sociology to build.

At about the same time, Robbins at the London School of Economics was working on a radical redefinition of the scope and boundaries of economics. Particularly influenced by economists of the Austrian school, Robbins redefined economics as the universal 'science of choice'. For him, economics was about the rational choice of means to serve given ends. The 'economic problem' was then to determine the best means available to meet those given ends. It applied to all economic systems, as long as there were choices to be made and a scarcity of resources. Economics was no longer defined in terms of a real object or zone of analysis, but in terms of specific assumptions and methods.

Parsons (1934) appraised Robbins's (1932) influential book in an important essay in the Quarterly Journal of Economics. For Parsons, in contrast to Robbins, ends and means could not entirely be separated. Furthermore, ends could not always be taken as 'given' because they were likely to be affected by the processes involved in their attainment. Second, Parsons stressed that social action was always framed and driven by social and institutional norms.

Crucially, however, Parsons did not reject to this redefinition of economics. In fact, it served his purposes. By defining economics narrowly, as the science of rational choice, Robbins conceded a substantial territory to the sociologist. For Parsons, sociology was about the social and normative origin of the ends that Robbins had taken as given.

Parsons's tactic was to show that Robbinsian economics had to be grounded upon a general sociological theory. Economics would focus merely on the examination of the logical relationships between means and given ends. Sociology would then assume its place as the study of the social origin of the ends. Hence, Parsons (1937, p. 768) defined sociology as 'the science which attempts to develop an analytical theory of social action systems in so far as these systems can be understood in terms of the property of common-value integration.' This definition of the subject was not in terms of the analysis of 'social action systems' as a whole, but in terms of the impact and integration of common values. Sociology was thus defined as the study of an aspect of the social system. It had a delineated domain of enquiry. The study of other features was conceded to economists and others.

An implicit contract emerged between both economists and sociologists. Economics was henceforth to concerns itself with the rational choice of means to serve given ends; sociology was to be concerned with the explanation of those values and ends. With Robbins (1932), economics became the 'science of choice' without much consideration of what 'choice' actually meant in philosophical terms. Under Parsons (1937, p. 768) sociology was reconstructed as 'the science ... of social action' without much discussion of the materialist causes behind intention or action itself.

Crucially, both Parsons and Robbins avoided any direct and integrated analysis of socioeconomic structures and institutions as a whole. Each of them focused on a selected analytical aspect. Each science was defined in terms of concepts and assumptions, rather than real objects of enquiry. Neither addressed the structured reality in its totality. By contrast, Schumpeter retained a strong integrating ambition in his work.

Both economics and sociology became redefined in terms of the study of types of analytical problem rather than in terms of the explanation of a distinct reality. They became 
compartmentalised, self-reflective discourses. After Parsons and Robbins, no social science addressed the study of socio-economic systems as a whole. The Comtean vision of a unified social science was finally abandoned.

Samuelson was a student of Schumpeter at Harvard in the 1930s. When Samuelson (1947, 1948) re-laid the foundations of postwar neoclassical economics and published his bestselling textbook, he adopted Robbins's definition of economics. Samuelson synthesized the approaches of Walras and Pareto in microeconomics with a version of Keynesian macroeconomics. Following Robbins, he took individual preference functions as given.

It is inconceivable that Schumpeter did not discussed the boundaries between economics and sociology with Parsons. Schumpeter's ideas on this topic probably influenced both Parsons and Samuelson, although neither adopted them in exact terms. On the other side of the Atlantic, Robbins (1932) made several references to Schumpeter (1908), including criticism of Schumpeter's definition of economics as the science of 'exchange relations'.

At least until the 1970s, the Parsonian approach dominated sociology, along with his conception of the scope and boundaries of the subject. Despite the huge influence of Marshall, especially in the first half of the twentieth century, economics in the second half generally defined itself in narrower and Robbinsian terms, as the 'science of choice' taking purposes or preferences as given.

Although Schumpeter's extensive involvement in discussions with Parsons is well documented, there is no evidence that he approved of the emerging Robbins-Parsons consensus on the boundaries of economics and sociology. However, apart from such rare instances, it is also remarkable that he seemed reluctant to declare openly and forcefully his views on the legitimate and more inclusive boundaries of economics, at a critical time.

One of the mysteries concerning Schumpeter's role in this major redefinition of disciplinary boundaries was that he did not intervene more strongly, especially given his emphasis on economic evolution and dynamic transformation. Statements to this effect in the crucial period of the 1930s are extremely rare, despite his close connections at Harvard with two of the three most important players involved.

For example, in his 1937 preface to the Japanese edition of the Theory of Economic Development, he criticized Walras for conceiving of economic theory in static terms. Schumpeter also rejected the view that 'as economic theorists we cannot say much about the factors that account for historical changes'. He called instead for 'a purely economic theory of economic change' and upheld that he was trying to build such a theory (Clemence, 1951, pp. 159-60). There is a significant contrast here with his 1908 position.

On the other hand, we have to take into account the later statement, quoted above, where Schumpeter (1954, p. 21) describes 'economic analysis' and 'economic sociology' in terms that are consistent with the postwar Robbins-Parsons consensus on the boundaries between economics and sociology. Furthermore, during the 1930s and 1940s Schumpeter witnessed the much-delayed rise in popularity of the Walrasian general equilibrium approach, which Schumpeter himself had championed many years earlier.

However, in his final essay, there is a hint that he was worried about some of the consequences of the Robbins-Parsons consensus and the rise of general equilibrium theory. His concern was that the study of historical and institutional factors would be diminished within economics, as the discipline became more focused on formal models. Schumpeter (1951, p. 308) thus wrote: 'there is an argument for historical or institutional study in almost any department of economics.' 
But it was too little and too late. The Robbins-Parsons redefinitions had already taken hold. Contrary to Schumpeter's personal example and inclinations, economics recast as the narrower 'science of choice' rapidly underwent a 'formalistic revolution' (Ward, 1972; Blaug, 1999, 2003) and excluded many Marshallian concerns from the very scope of 'economics' itself.

It seems overall that Schumpeter played an equivocal rather than a leading or decisive role in the recasting of the boundaries of economics in the 1930s and 1940s. Significantly, in the crucial debates of the 1930s, he mounts no strong defence of broader boundaries in any work intended for an English-speaking audience. In that critical decade he failed to challenge openly and directly the budding Robbins-Parsons consensus. But there is some evidence in the last years of his life that he was concerned about the emerging outcome.

\section{Conclusion: The End of the Parson-Robbins Consensus and the Need for Redefinition}

It has been shown above that Schumpeter was involved in intellectual circles that changed the prevailing definition of economics from the Marshallian study of the 'ordinary business of life' to the narrower Robbinsian 'science of choice' and shifted the definition of sociology from the Comtean science of society to the Parsonian emphasis on the origin and integration of values. Schumpeter at least played the role of a catalyst in this shift, although the outcome was significantly different from his own various views on the boundaries of 'economics' or 'economic theory'.

The Robbins-Parsons conceptions of the nature and boundaries of both economics and sociology endured from the 1930s to the 1980s. The result of the Robbins-Parsons settlement was that economics and sociology were each concerned with an aspect of the social system as a whole. 'Sociology' existed, but no science was devoted to the study of the whole society. 'Economics' endured, but no science was principally devoted to the study of the economy as such. Ironically, despite his role in this schism, Schumpeter's own work retained a strong integrative and interdisciplinary character.

However, by the end of the twentieth century, the Robbins-Parsons settlement had crumbled. The core concepts in each discipline came under attack. Furthermore, researchers calling themselves 'economists' or 'sociologists' enthusiastically trespassed on the traditional domain of the other discipline. We can observe both these effects in each discipline, involving challenges to core ideas and open trespassing on territories claimed by other disciplines.

Within sociology, the Parsonian hegemony eventually crumbled after sustain criticism from all sides. Due to James Coleman (1990) and others, rational actor models invaded sociology as well as political science.

On the other side, 'economists' such as Gary Becker (1981) ventured into the 'sociological' territory of marriage and the family. Also, within economics, game theory showed that the concept of rationality was itself insufficiently well-specified, and experimental economists became increasingly persuaded by evidence that seemed to undermine the rationality assumption (Sugden, 1991; Kahneman, 1994; Kagel and Roth, 1995). In contrast to the former emphasis on given preferences, several leading economists now admit endogenous and situation-dependent preference formation in economics (Akerlof and Kranton, 2005; Bowles, 1998, 2004). ${ }^{10}$ Based in part on evidence from interviews of graduate students at the most

\footnotetext{
10 A much earlier admission is found in Hammond (1976).
} 
prestigious departments of economics, David Colander (2005b, p. 930) has studied how the next generation of mainstream economists are abandoning the "holy trinity" assumptions of rationality, greed and equilibrium.' 11

Consequently, with the erosion of core concepts on both sides, the very meaning and identity of 'economics' and 'sociology' are open to question. Furthermore, previously established frontiers between the disciplines are being transgressed from both sides. Despite claims to the contrary, there are no adequately specified accounts that 'economics' or 'sociology' can be defined in terms of their core methods or results (Kalleberg, 1995; Velthuis, 1999; Zafirovski, 1999; Rojas, 2006; Hodgson, 2007). Particular methodological claims and related definitions are contested by multiple dissenting voices from within each discipline.

These circumstances call for a concerted re-examination of the boundaries between economics and sociology, the nature of each subject and its subject matter, and the subdivisions within the social sciences as a whole. This is one the most important - but hitherto neglected - tasks for economists and sociologists at the beginning of the twenty-first century. Yet I hazard to suggest that in such circumstances both Marshall and Schumpeter would have fully appreciated its urgency.

11 See also Colander (2005a), Colander et al. (2004a, 2004b), Davis (2006). 


\section{References}

Akerlof, George A. and Kranton, Rachel E. (2005) 'Identity and the Economics of Organizations', Journal of Economic Perspectives, 19(1), Winter, pp. 9-32.

Appel, Michael (1992) Werner Sombart: Historiker und Theoretiker des modernen Kapitalismus (Marburg: Metropolis).

Becker, Gary S. (1981) A Treatise on the Family (Cambridge, MA: Harvard University Press).

Blaug, Mark (1999) 'The Formalist Revolution or What Happened to Orthodox Economics After World War II?', in Backhouse, Roger E. and Creedy, John (eds) (1999) From Classical Economics to the Theory of the Firm: Essays in Honour of D. P. O'Brien (Cheltenham: Edward Elgar), pp. 257-80.

Blaug, Mark (2003) 'The Formalist Revolution of the 1950s', in Samuels, Warren J., Biddle, Jeff E. and Davis, John B. (eds) (2003) A Companion to the History of Economic Thought (Malden, MA and Oxford, UK: Blackwell), pp. 395-410.

Bowles, Samuel (1998) 'Endogenous Preferences: The Cultural Consequences of Markets and Other Economic Institutions', Journal of Economic Literature, 36(1), March, pp. 75-111.

Bowles, Samuel (2004) Microeconomics: Behavior, Institutions, and Evolution (Princeton, NJ and New York: Princeton University Press and Russell Sage Foundation).

Brick, Howard (1993) 'The Reformist Dimension of Talcott Parsons's Early Social Theory', in Haskell, Thomas L. and Teichgraeber, Richard F. (eds) (1993) The Culture of the Market: Historical Essays (Cambridge: Cambridge University Press), pp. 357-96.

Camic, Charles (1992) 'Reputation and Predecessor Selection: Parsons and the Institutionalists', American Sociological Review, 57(4), August, pp. 421-45.

Chaloupek, Günther K. (1995) 'Long-Term Economic Perspectives Compared: Joseph Schumpeter and Werner Sombart', European Journal of the History of Economic Thought, 2(1), pp. 127-49.

Clemence, Richard V. (ed.) (1951) Essays on Economic Topics of J. A. Schumpeter (Cambridge, UK and Port Washington, NY: Cambridge University Press and Kennikat).

Colander, David C. (2005a) 'The Making of an Economist Redux', Journal of Economic Perspectives, 19(1), Winter, pp. 175-98.

Colander, David C. (2005b) 'The Future of Economics: The Appropriately Educated in Pursuit of the Knowable', Cambridge Journal of Economics, 29(6), November, pp. 927-41.

Colander, David C., Holt, Richard P. F. and Rosser, J. Barkley, Jr. (2004a) The Changing Face of Economics: Interviews with Cutting Edge Economists (Ann Arbor, MI: University of Michigan Press).

Colander, David C., Holt, Richard P. F. and Rosser, J. Barkley, Jr. (2004b) 'The Changing Face of Economics', Review of Political Economy, 16(4), October, 485-499.

Coleman, James S. (1990) Foundations of Social Theory (Cambridge, MA: Harvard University Press). 
Cunningham, William (1892) 'The Relativity of Economic Doctrines', Economic Journal, 2(1), March, pp. 1-16.

Davis, John B. (2006) 'The Turn in Economics: Neoclassical Dominance to Mainstream Pluralism?' Journal of Institutional Economics, 2(1), April, pp. 1-20.

Ebner, Alexander (2000) 'Schumpeter and the "Schmollerprogramm": Integrating Theory and History in the Analysis of Economic Development', Journal of Evolutionary Economics, 10(3), pp. 355-72.

Edgeworth, Francis Y. (1891) 'The British Economic Association', Economic Journal, 1(1), March, pp. 1-2.

Ekelund, Robert B. Jr. and Hébert, Robert F. (2002) 'The Origins of Neoclassical Economics', Journal of Economic Perspectives, 16(3), Summer, pp. 197-215.

Fligstein, Neil (2001) The Architecture of Markets: An Economic Sociology of Twenty-First Century Capitalist Societies (Princeton, NJ: Princeton University Press).

Hammond, Peter J. (1976) 'Changing Tastes and Coherent Dynamic Choice', Review of Economic Studies, 43(1), February, pp. 159-173.

Hodgson, Geoffrey M. (1988) Economics and Institutions: A Manifesto for a Modern Institutional Economics (Cambridge and Philadelphia: Polity Press and University of Pennsylvania Press).

Hodgson, Geoffrey M. (2001) How Economics Forgot History: The Problem of Historical Specificity in Social Science (London and New York: Routledge).

Hodgson, Geoffrey M. (2005) 'Alfred Marshall versus the Historical School?' Journal of Economic Studies, 32(4), 2005, pp. 331-48.

Hodgson, Geoffrey M. (2007) 'Prospects for Economic Sociology', Philosophy of the Social Sciences, forthcoming.

Hutchison, Terence W. (1988) 'Gustav Schmoller and the Problems of Today', Journal of Institutional and Theoretical Economics, 144(3), pp. 527-531.

Jevons, William Stanley (1888) The Theory of Political Economy, $3^{\text {rd }}$ edn. (London: Macmillan).

Joas, Hans (1995) 'Communitarianism, Pragmatism, Historicism', in Koslowski, Peter (ed.) (1995) The Theory of Ethical Economy in the Historical School: Wilhelm Roscher, Lorenz. von Stein, Gustav Schmoller, Wilhelm Dilthey and Contemporary Theory (Berlin: Springer), pp. 267-85.

Kagel, John H. and Roth, Alvin E. (eds) (1995) The Handbook of Experimental Economics (Princeton: Princeton University Press).

Kahneman, Daniel (1994) 'New Challenges to the Rationality Assumption', Journal of Institutional and Theoretical Economics, 150(1), pp. 18-36.

Kalleberg, Arne L. (1995) 'Sociology and Economics: Crossing the Boundaries', Social Forces, 73(4), June, pp. 1207-18.

Keynes, John Maynard (1936) The General Theory of Employment, Interest and Money (London: Macmillan).

Lie, John (1997) 'Sociology of Markets’, Annual Review of Sociology, 23, pp. 341-60. 
Machlup, Fritz (1951) 'Schumpeter's Economic Methodology', Review of Economics and Statistics, 33(2), May, pp. 145-51.

Marshall, Alfred (1885) 'The Present Position of Economics', in Arthur C. Pigou (ed.) (1925) Memorials of Alfred Marshall (London: Macmillan), pp. 152-74.

Marshall, Alfred (1890) Principles of Economics: An Introductory Volume, 1st edn. (London: Macmillan).

Marshall, Alfred (1892) 'A Reply to "The Perversion of Economic History" by Dr. Cunningham', Economic Journal, 2, pp. 507-19.

Marshall, Alfred (1897) 'The Old Generation of Economists and the New', Quarterly Journal of Economics, 11, pp. 115-35.

Marshall, Alfred (1907) 'The Social Possibilities of Economic Chivalry', Economic Journal, 17(1), March, pp. 7-29.

Marshall, Alfred (1920) Principles of Economics: An Introductory Volume, 8th edn. (London: Macmillan).

Mathews, John A. (2002) 'Introduction: Schumpeter's "Lost” Seventh Chapter', Industry and Innovation, 9(1-2), April-August, pp. 1-5.

Menger, Carl (1883) Untersuchungen über die Methode der Sozialwissenschaften und der politischen Ökonomie insbesondere (Tübingen: J. C. B. Mohr). Published in English as Menger, Carl (1985) Investigations into the Method of the Social Sciences with Special Reference to Economics (New York: New York University Press).

Menger, Carl (1985) Investigations into the Method of the Social Sciences with Special Reference to Economics [English translation of Menger (1883)] (New York: New York University Press).

Mitchell, Wesley C. (1916) 'The Role of Money in Economic Theory', American Economic Review (Papers and Proceedings), 6(1), pp. 140-61.

Mitchell, Wesley C. (1969) Types of Economic Theory: From Mercantilism to Institutionalism, 2 vols., ed. J. Dorfman (New York: Augustus Kelley).

Mittermaier, K. H. M. (1992) 'Ludwig Lachmann (1906-1990): A Biographical Sketch', South African Journal of Economics', 60(1), pp. 7-23.

Pareto, Vilfredo (1935) The Mind and Society, 4 vols., translated from the Italian edition of 1923 by A. Bongiorno and A. Livingston, and edited by A. Livingston (London: Jonathan Cape).

Pareto, Vilfredo (1971) Manual of Political Economy, translated from the French edition of 1927 by A. S. Schwier, and edited by A. S. Schwier and A. N. Page (New York: Augustus Kelley).

Parsons, Talcott (1934) 'Some Reflections on "The Nature and Significance of Economics"،, Quarterly Journal of Economics, 48(3), May, pp. 511-45.

Parsons, Talcott (1937) The Structure of Social Action, 2 vols (New York: McGraw-Hill).

Parsons, Talcott (1970) 'On Building Social Systems Theory: A Personal History', Daedalus, Winter, pp. 826-81. 
Robbins, Lionel (1932) An Essay on the Nature and Significance of Economic Science, 1st edn. (London: Macmillan).

Rojas, Fabio (2006) 'Sociological Imperialism in Three Theories of the Market', Journal of Institutional Economics, 2(3), December, pp. 339-63.

Samuelson, Paul A. (1947) Foundations of Economic Analysis (Cambridge, MA: Harvard University Press).

Samuelson, Paul A. (1948) Economics, 1st edn. (New York: McGraw-Hill).

Schmoller, Gustav (1900) Grundriss der allgemeinen Volkswirtschaftslehre, Erster Teil (München und Leipzig: Duncker und Humblot).

Schumpeter, Joseph A. (1908) Das Wesen und der Hauptinhalt der theoretischen Nationalökonomie (München und Leipzig: Duncker und Humblot).

Schumpeter, Joseph A. (1909) 'On the Concept of Social Value', Quarterly Journal of Economics, 23(2), February, pp. 213-32.

Schumpeter, Joseph A. (1912) Theorie der wirtschaftlichen Entwicklung: Eine Untersuchung über Unternehmergewinn, Kapital, Kredit, Zins und den Konjunkturzylkus (München und Leipzig: Duncker und Humblot).

Schumpeter, Joseph A. (1926a) 'Gustav v. Schmoller und die Probleme von heute', Schmollers Jahrbuch für Gesetzgebung, Verwaltung und Volkwirtschaft im Deutschen Reiche, 50, pp. 1-52.

Schumpeter, Joseph A. (1926b) Theorie der wirtschaftlichen Entwicklung: Eine Untersuchung über Unternehmergewinn, Kapital, Kredit, Zins und den Konjunkturzylkus, $2^{\text {nd }}$ edn. (München und Leipzig: Duncker und Humblot).

Schumpeter, Joseph A. (1928) 'The Instability of Capitalism', Economic Journal, 38, pp. 36186. Reprinted in Clemence (1951).

Schumpeter, Joseph A. (1930) 'Mitchell's Business Cycles', Quarterly Journal of Economics, 45(1), November, pp. 150-72.

Schumpeter, Joseph A. (1931) 'The Present World Depression: A Tentative Diagnosis', American Economic Review Review (Papers and Proceedings), 21(1), Supplement, March, pp. 179-82.

Schumpeter, Joseph A. (1934) The Theory of Economic Development: An Inquiry into Profits, Capital, Credit, Interest, and the Business Cycle, translated by Redvers Opie from the second German edition of 1926, first edition 1911 (Cambridge, MA: Harvard University Press).

Schumpeter, Joseph A. (1941) 'Alfred Marshall's Principles: a Semi-Centennial Appraisal', Amerucan Economic Review, 31(2), June, pp. 236-48.

Schumpeter, Joseph A. (1942) Capitalism, Socialism and Democracy (London: George Allen and Unwin).

Schumpeter, Joseph A. (1951) 'The Historical Approach to the Analysis of Business Cycles' in Richard V. Clemence (ed.) (1951) Essays on Economic Topics of J. A. Schumpeter (Port Washington, NY: Kennikat), pp. 308-15.

Schumpeter, Joseph A. (1954) History of Economic Analysis (Oxford and New York: Oxford University Press). 
Schumpeter, Joseph A. (1991) The Economics and Sociology of Capitalism, edited by Richard Swedberg (Princeton: Princeton University Press).

Schumpeter, Joseph A. (2002) 'The Economy as a Whole: Seventh Chapter of the Theory of Economic Development', translated by Ursula Backhaus from Schumpeter (1912), Industry and Innovation, 9(1-2), April-August, pp. 93-145.

Shionoya, Yuichi (1990) 'The Origin of the Schumpeterian Research Program: A Chapter Omitted from Schumpeter's Theory of Economic Development', Journal of Institutional and Theoretical Economics, 146(2), June, pp. 314-27.

Shionoya, Yuichi (1997) Schumpeter and the Idea of Social Science: A Metatheoretical Study (Cambridge and New York: Cambridge University Press).

Shove, Gerald F. (1942) 'The Place of Marshall's Principles in the Development of Economic Theory', Economic Journal, 52(4), December, pp. 294-329.

Skidelsky, Robert (1983) John Maynard Keynes: Volume One: Hopes Betrayed, 1883-1920 (London: Macmillan).

Solow, Robert M. (1990) The Labor Market as a Social Institution (Oxford: Basil Blackwell).

Sombart, Werner (1913) Krieg und Kapitalismus (München und Leipzig: Duncker und Humblot).

Sombart, Werner (1929) 'Economic Theory and Economic History', European History Review, 2(1), January, pp. 1-19.

Streissler, Erich W. (1994) 'The Influence of German and Austrian Economics on Joseph A. Schumpeter', in Shionoya, Yuichi and Perlman, Mark (eds) (1994) Schumpeter in the History of Ideas (Ann Arbor, MI: University of Michigan Press).

Sugden, Robert (1991) 'Rational Choice: A Survey of Contributions from Economics and Philosophy', Economic Journal, 101(4), July, pp. 751-85.

Swedberg, Richard (1989) 'Joseph A. Schumpeter and the Tradition of Economic Sociology', Journal of Institutional and Theoretical Economics, 145, pp. 508-24.

Veblen, Thorstein B. (1900) 'The Preconceptions of Economic Science: III', Quarterly Journal of Economics, 14(2), February, pp. 240-69.

Velthuis, Olav (1999) 'The Changing Relationship between Economic Sociology and Institutional Economics: From Talcott Parsons to Mark Granovetter', American Journal of Economics and Sociology, 58(4), October, pp. 629-49.

Ward, Benjamin (1972) What's Wrong With Economics? (London: Macmillan).

Whitaker, John K. (ed.) (1996) The Correspondence of Alfred Marshall, 3 vols (Cambridge: Cambridge University Press).

Zafirovski, Milan (1999) 'Economic Sociology in Retrospect and Prospect: In Search of Its Identity within Economics and Sociology', American Journal of Economics and Sociology, 58(4), October, pp. 583-627.

Zaret, David (1980) 'From Weber to Parsons and Schultz: The Eclipse of History in Modern Social Theory', American Journal of Sociology, 85(5), March, pp. 1180-201. 